\title{
PENINGKATAN KOMITMEN TERHADAP PROFESI MELALUI PENGUATAN PEMBERDAYAAN DAN EFIKASI DIRI GURU SMP SWASTA
}

\author{
Lisnawati Suparta $^{a)}$, Widodo Sunaryo ${ }^{b)}$, Entis Sutisna ${ }^{b *}$ \\ ${ }^{a)}$ SMA Sukabumi, Sukabumi, Indonesia \\ ${ }^{b)}$ Universitas Pakuan, Bogor, Indonesia \\ *)e-mail korespondensi: entis.sutisna@unpak.ac.id
}

riwayat artikel : diterima: 18 Juni 2020; direvisi: 27 Juni 2020; disetujui: 16 Juli 2020

\begin{abstract}
Abstrak. Penelitian ini bertujuan untuk mengetahui peningkatan Komitmen terhadap Profesi dengan melihat hubungannya dengan Pemberdayaan dan Efikasi Diri Guru SMP Swasta se Kecamatan Tapos Depok. Jumlah sampel penelitian sebanyak 106 guru yang diambil menggunakan teknik proportional random sampling. Metode yang digunakan adalah metode korelasional. Pengujian hipotesis yang dilakukan dengan menggunakan analisis statistik parametrik dalam bentuk analisis regresi linier sederhana dan berganda, analisis korelasi sederhana dan berganda serta analisis parsial dengan taraf signifikansi $\alpha=0,01$ dan $\alpha=0,05$. Penelitian ini menghasilkan tiga kesimpulan. Pertama, terdapat hubungan positif dan signifikan yang moderate antara variabel pemberdayaan dengan komitmen terhadap profesi dengan koefisien korelasi $r_{\mathrm{yl}}=0,63$, koefisien determinasi $\mathrm{R}_{\mathrm{yl}}{ }^{2}=0,4026$. Kedua, terdapat hubungan positif dan signifikan yang tinggi antara variabel efikasi diri dengan komitmen terhadap profesi dengan koefisien korelasi $r_{\mathrm{y} 2}=0,81$, koefisien determinasi $\mathrm{R}_{\mathrm{y} 2}{ }^{2}=0,6580$. Ketiga, terdapat hubungan positif dan signifikan yang tinggi antara variabel pemberdayaan (X1) dan efikasi diri (X2) secara bersama-sama dengan komitmen terhadap profesi dengan koefisien korelasi $r_{\mathrm{y} .12}=0,834$ dan koefisien determinasi $\mathrm{R}_{\mathrm{y} .12}{ }^{2}=0,696$. Dapat disimpulkan bahwa variabel komitmen terhadap profesi dapat ditingkatkan melalui penguatan variabel pemberdayaan dan efikasi diri.
\end{abstract}

Kata Kunci: komitmen terhadap profesi; pemberdayaan; efikasi diri

\section{IMPROVEMENT OF COMMITMENT TO PROFESSION THROUGH STRENGTHENING EMPOWERMENT AND SELF-EFFICATION OF PRIVATE SMP TEACHERS}

\begin{abstract}
This study is intended to determine the increase of organizational commitment by studying its correlation with Empowerment and Self-Efficacy of Private Junior High School Teachers located in Tapos District, Depok. The number of research samples were 106 teachers which were taken by using proportional random sampling techniques. The method used was the correlational method. Hypothesis testing was carried out using parametric statistical analysis in the form of simple and multiple linear regression analysis, simple and multiple correlation analysis and partial analysis where the significance levels $\alpha=0.01$ and $\alpha=0.05$. This study came up with three conclusions. Firstly, there was a moderate positive and significant relationship between the variables of empowerment and organizational commitment with a correlation coefficient $r_{y 1}=0.63$, a coefficient of determination $R_{y 1}^{2}=0.4026$. Secondly, there was a high positive and significant relationship between the variable of self-efficacy and organizational commitment with a correlation coefficient $r_{\mathrm{y} 2}=0.81$, and the coefficient of determination $\mathrm{R}_{\mathrm{y} 2}{ }^{2}=0.6580$. Thirdly, there was a high positive and significant relationship between the empowerment variable (X1) and self-efficacy (X2) together with organizational commitment with a correlation coefficient $r_{y .12}=0.834$ and a coefficient of determination $R_{y .12}{ }^{2}=0.696$. It couldn be concluded that the organizational commitment variable might be increased by strengthening the empowerment and self-efficacy variables.
\end{abstract}

Keywords: organizational commitment; empowerment; self-efficacy.

\section{PENDAHULUAN}

Guru memegang peranan penting dalam mewujudkan cita-cita pendidikan nasional yang tercantum dalam UUD 1945 yakni "mencerdaskan kehidupan bangsa." Hal ini mengandaikan adanya perhatian yang serius pada faktor yang mempengaruhi tingkat komitmen guru di sekolah dan dalam sistem pendidikan yang lebih luas, seperti pada bidang penelitian yang mengarah pada pengenalan reformasi dan perubahan di dalam ruang kelas, sekolah, lembaga, pusat pembelajaran, dan sistem pendidikan nasional. Pendidikan yang berkualitas tidak dapat dicapai tanpa peran dari guru yang berdedikasi dan berkomitmen tinggi. Guru yang berkomitmen menanamkan dan memelihara implementasi nilai-nilai pembelajaran baik pengetahuan dan keterampilan di dunia yang lebih luas lagi. Ada dua alasan mengapa komitmen guru harus ditekankan dalam bidang pendidikan. Pertama, komitmen adalah kekuatan internal yang berasal dari dalam diri guru yang memiliki kebutuhan akan tanggung jawab, variasi, dan tantangan yang lebih besar dalam pekerjaan mereka seiring dengan meningkatnya tuntutan tingkat partisipasi mereka dalam pendidikan. Kedua, ada pengaruh eksternal yang menuntut adanya pembaruan dan pengembangan dalam pendidikan, menetapkan standar yang lebih tinggi dan akuntabilitas yang lebih besar, yang semuanya menuntut agar guru di sekolah lebih berkomitmen untuk menciptakan pembelajaran yang lebih baik. Guru yang memiliki komitmen tinggi akan muncul dalam 
dirinya semangat untuk mengabdi. Semangat pengabdian yang tingi dari seorang guru akan menumbuhkan sikap tanggung jawab guru dalam melaksanakan tugas-tugasnya dengan sepenuh hati. Sikap tanggung jawab ini sangat penting dalam menumbuhkan usaha untuk menciptakan situasi pembelajaran yang berkualitas yang pada akhirnya diharapakan dari pembelajaran yang berkualitas ini akan melahirkan siswa-siswa yang berkualitas pula. Disamping itu guru yang berkomitmen tinggi terhadap profesinya akan dengan sepenuh hati mengabdikan seluruh hidupnya untuk kemajuan pendidikan dan melakukan tugasnya, bukan sekedar menggugurkan kewajiban. Orientasi kerjanya bukan lagi "apa yang dapat saya peroleh" melainkan "apa yang dapat saya berikan".

Guru merupakan unsur pendidikan yang sangat dekat dengan peserta didik dalam upaya pendidikan sehari-hari dan banyak menentukan keberhasilan peserta didik dalam mencapai tujuan. Peranan guru semakin penting pada era global. Hanya melalui bimbingan yang profesional, setiap peserta didik dapat menjadi sumber daya manusia yang berkualitas, kompetitif, dan produktif sebagai aset nasional dalam menghadapi persaingan yang makin ketat dan berat, sekarang dan di masa yang akan datang. Namun faktanya, tidak sedikit guru di Indonesia masih memilki komitmen belum sesuai dengan harapan. Hasil penelitian yang dilakukan oleh ACDP (Analytical and Capacity Development ) sekitar 9,7\% guru di Indonesia tak hadir di sekolah. Rendahnya kehadiran guru menjadi salah satu penyebab kecilnya angka partisipasi murid, terutama di wilayah miskin dan terpencil. Bahkan, ketidakhadiran guru turut menjadi alasan siswa tak bersekolah. Hasil Uji Kompetensi Guru (UKG) tahun 2015 menyebutkan bahwa rata-rata UKG secara nasional 53,02. Rerata nilai kompetensi profesional 54,77, nilai rata-rata kompetensi pedagogik 48,94 sedangkan pemerintah menargetkan rata - rata nilai diangka 55 (Kemdikbud, 30/12/2015). Ini menunjukkan bahwa secara nasional kompetensi guru masih harus ditingkatkan. Hasil survei yang dilakukan United Nations Development Program (UNDP) tentang peringkat indeks pembangunan manusia menunjukkan bahwa jika dibandingkan dengan negara-negara tetangga, posisi Indonesia jauh tertinggal. Di antara 174 negara yang di survei, peringkat Indonesia dari tahun ke tahun selalu berada pada zona yang rendah

Menurut Goswami, Mathew dan Chada (2007:13) Komitmen kerja dan komitmen profesional memiliki arti dan pertukaran yang sama. Komitmen pekerjaan disebut sebagai hubungan psikologis antara individu dan pekerjaannya yang didasarkan pada reaksi afektif terhadap pekerjaan itu. Lee, Carswell, and Allen dalam Sezgin dan Ağar (2012:21) mengemukakan konsep mengenai komitmen terhadap profesi yaitu istilah pekerjaan, profesi, dan karier telah digunakan secara bergantian dalam literatur komitmen dan komitmen yang ditetapkan untuk pekerjaan seseorang sebagai kekuatan relatif dari identifikasi dan keterlibatan dalam suatu profesi, serta kemauan untuk mengerahkan usaha atas nama profesi dan keinginan untuk mempertahankan keanggotaan di dalamnya pada profesi tersebut. Menurut Wang \& Shen (2012: 156) komitmen profesi adalah komitmen individu pada pekerjaannya dengan memandang pentingnya suatu profesi bagi keseluruhan kehidupannya dengan dimensi: A. Dimensi komitmen afektif terhadap profesi dengan indikator terdiri dari (a) keterikatan emosional; B. Dimensi komitmen Normatif terhadap profesi dengan indikator terdiri dari (a) norma kelompok; C. Dimensi komitmen Berkelanjutan terhadap profsi dengan indikator (a) pengukuran biaya. Selain teori yang dikemukakan diatas, Cho dan Huang (2012:31) juga menjelaskan mengenai komitmen terhadap profesi yaitu mengacu pada kekuatan identifikasi individu dengan suatu profesi. Individu dengan komitmen profesional yang tinggi dicirikan memiliki keyakinan dan penerimaan yang kuat terhadap tujuan profesi, kemauan untuk mengerahkan upaya yang besar atas nama profesi, dan keinginan kuat untuk mempertahankan keanggotaan dalam profesi. Dari teori di atas dapat disintesiskan bahwa Komitmen terhadap profesi adalah keinginan seseorang untuk mengidentifikasi dirinya terhadap suatu profesi dan ingin terlibat penuh pada profesinya serta ingin mempertahankan keberadaannya pada profesi tersebut. Adapun dimensi dan indikatornya adalah: A. Dimensi Komitmen Afektif terhadap profesi dengan indikator terdiri dari (a) keterikatan emosional (b) identifikasi diri (c) keterlibatan dalam organisasi; B. Dimensi Komitmen berkelanjutan terhadap profesi terdiri dari indikator-indikator (a) Keuntungan/manfaat yang diterima (b) Biaya yang terkait; C. Dimensi Komitmen Afektif terhadap profesi terdiri dari indikator-indikator (a) Perasaan kewajiban untuk tetap dalam pekerjaan (b) Rasa tanggung jawab terhadap pekerjaan.

Pemberdayaan (empowerment) adalah upaya yang bertolak dari keyakinan bahwa sesorang dapat memberikan kontribusi dalam mengerjakan tugas-tugas dan pekerjaan dalam rangka pencapaian tujuan organisasi dan tujuan pribadinya, dengan indikator seperti determinasi diri yaitu menumbuhkan pada diri individu rasa mampu menentukan pilihan, meaning (pemaknaan pekerjaan) yaitu membuat seseorang merasa bersemangat dan berkontribusi, kompeten yang menumbuhkan rasa percaya pada kemampuan (kapasitas) diri, Impact (dampak atas hasil kerja yang dicapai) (Colquitt, Lepine dan Wetson 2011 : 198). Pemberdayaan dilihat juga sebagai kondisi psikologis individu dimana individu merasa lebih memiliki determinasi diri, merasa berarti, kompeten dan hasil kerjanya memiliki dampak terhadap organisasi mengenai pemberdayaan dengan indikator seperti determinasi diri, meaning yang memperlihatkan pekerjaan yang digeluti memberi arti penting, kompeten, impact (McShane dan Glinow, 2010:182). Sejalan dengan teori di atas, Amzat dan Valdez (2017: 200) mengemukakan bahwa memberdayakan adalah jenis mekanisme untuk meningkatkan kepercayaan. Ini menanamkan rasa otonomi untuk mengejar pertumbuhan pribadi dan profesional agar tetap relevan di bidang yang digeluti. Pemberdayaan terdiri atas faktor struktural seperti akses ke sumber daya penting dan kondisi kerja yang memungkinkan untuk mempertahankan kontrol atas pengambilan keputusan yang penting untuk pembelajaran siswa, serta faktor-faktor individual seperti efikasi diri dan kepercayaan diri akan pentingnya internal pekerjaan sehari-hari mereka yang mendukung persepsi tentang pertumbuhan dan efektivitas mereka sendiri (Rice, 2017: 12). Dari teoriteori diatas dapat disintesiskan bahwa Pemberdayaan (empowerment) adalah suatu pemberian kesempatan yang diberikan pimpinan kepada individu (bawahan) untuk mengaktualisasikan potensi dirinya dalam rangka mencapai tujuan organisasi. 
Ivancevich (2010:217) Efikasi diri adalah keyakinan bahwa seseorang dapat berkinerja baik dalam situasi tertentu, dengan beberapa indikator seperti, termotivasi untuk terlibat (magnitude), belajar lebih banyak dan mentransfer (strenght), dan (c) mengarahkan (dirinya sendiri) ke level yang lebih tinggi (generality) dari penetapan tujuan dan kinerja. Menurut Chatzistamatiou dan Bagiatis (2013:3) efikasi diri adalah keyakinan seseorang pada kemampuan mereka untuk mengatur dan melaksanakan tindakan yang diperlukan untuk berhasil menyelesaikan tugas mengajar, dengan beberapa aspek pentin seperti (a) Pengaturan Mandiri yang mana pengaturan diri terbagi dalam tiga fase siklus yaitu pemikiran sebelumnya, kinerja atau kontrol kehendak, dan refleksi diri, (b) Kompetensi yaitu persepsi diri terkait dapat mempengaruhi pengembangan nilai tugas, (c) Kinerja melibatkan proses yang terjadi selama upaya seseorang dan memengaruhi perhatian dan tindakan, (d) Evaluasi Diri melibatkan proses yang terjadi setelah kinerja. Teori lain mengenai efikasi diri dikemukakan oleh Luthans (2008: 210) yang menyatakan bahwa efikasi diri adalah persepsi atau keyakinan individu bahwa ia dapat berhasil menyelesaikan tugas tertentu dengan dimensi; A. Magnitude dengan indikator (a) kesulitan tugas (b) keyakinan mampu melakukan, B. Strenght dengan indikator (a) Kekuatan menunjukkan apakah besarnya kuat dan cenderung menghasilkan ketekunan ketika kesulitan ditemui, dan C. Generality dengan indikator (a) tingkat tujuan yang dipilih, (b) reaksi seseorang ketika masalah ditemui dalam kemajuan menuju tujuan. Sejalan dengan konsep diatas, Major (2016:34) menerangkan bahwa efikasi diri adalah penilaian subyektif terhadap kemampuan seseorang untuk mengatur dan melaksanakan tindakan untuk mencapai tujuan yang ditentukan. Berdasarkan teori-teori yang dikemukakan di atas dapat disintesiskan bahwa Efikasi Diri adalah keyakinan individu untuk menyelesaikan tugas tertentu disertai tingkat pencapaian tertentu

\section{METODE PENELITIAN}

Penelitian ini menggunakan 106 sampel Guru Tetap Yayasan (GTY) SMP Swasta yang ada di Kecamatan Tapos Kota Depok, yang ditentukan dengan menggunakan teknik proportional random sampling. Populasi dalam penelitian ini adalah Guru Tetap Yayasan (GTY) SMP Swasta yang ada di Kecamatan Tapos Kota Depok. Data didapat dari dapodik masing-masing sekolah pada tahun 2019-2020 dengan jumlah guru 143 orang. Jumlah sampel yang diperoleh adalah 105,3 atau dibulatkan menjadi 106 orang guru

\section{HASIL DAN PEMBAHASAN}

\section{Hubungan Antara Pemberdayaan (XI) dengan Komitmen Terhadap Profesi (Y)}

Berdasarkan hasil perhitungan analisis regresi linier sederhana dan analisis korelasi sederhana, maka didapatkan bahwa hubungan antara variabel Pemberdayaan (Xl) dengan Komitmen Terhadap Profesi (Y) Guru SMP Swasta Sekecamatan Tapos Depok, dapat dinyatakan dalam bentuk persamaan garis lurus $\mathrm{Y}=68,833+0,454 \mathrm{Xl}$. Hal ini berarti bahwa setiap kenaikan satu unit Pemberdayaan akan menaikkan 0,454 unit Komitmen Terhadap Profesi. Hasil uji F pada analisis regresi linear sederhana memperlihatkan hubungan yang sangat signifikan kedua variabel ini. Hal ini mengindikasikan bahwa, adanya pengaruh Pemberdayaan terhadap Komitmen Terhadap Profesi Gum SMP Swasta Sekecamatan Tapos Depok. Sedangkan koefisien korelasi hubungan antara Pemberdayaan dan Komitmen Terhadap Profesi termasuk dalam kekuatan hubungan yang kuat (ry1= 0,63) dengan tingkat signifikansi sebesar 10,83 (sangat signifikan). Dengan demikian hasil penelitian ini menunjukkan bahwa terdapat hubungan positif yang signifikan dengan kekuatan hubungan yang kuat antara variabel Pemberdayaan dan Komitmen Terhadap Profesi. Perhitungan koefisien determinasi (ry12 sebesar 0,4026) menunjukkan variabel Pemberdayaan memberikan kontribusi sebesar sebesar 40,26\% terhadap kenaikan variabel Komitmen Terhadap Profesi (Y). 59,74\% disumbangkan oleh faktor lainnya seperti keterlibatan kerja, kepuasan kerja, kepribadian, dan situasi kerja. Penelitian ini mendukung penelitian terdahulu yang dilakukan oleh Boglera dan Somechb (2004: 121) yang berjudul "Influence of teacher empowerment on teachers' organizational commitment, professional commitment and organizational citizenship behavior in schools ", yang memberikan kesimpulan bahwa terdapat hubungan positif dan signifikan antara permberdayaan guru dan komitmen terhadap profesi dengan kekuatan hubungan $(r=0,68)$. Meskipun hasil koefisien korelasi pada penelitian-penelitian ini berbeda, namun semuanya memberikan kesimpulan yang sama yaitu bahwa terdapat hubungan positif yang sangat signifikan antara Pemberdayaan dengan Komitmen Terhadap Profesi.

\section{Hubungan Antara Efikasi Diri (X2) dengan Komitmen Terhadap Profesi (Y)}

Berdasarkan hasil perhitungan analisis regresi linier sederhana dan analisis korelasi sederhana, maka didapatkan bahwa hubungan antara variabel Efikasi Diri (X2) dengan Komitmen Terhadap Profesi (Y) Guru SMP Swasta Sekecamatan Tapos Depok, dapat dinyatakan dalam bentuk persamaan garis lurus $Y=28,23+0,816 X 2$. Hal ini berarti bahwa setiap kenaikan satu unit Efikasi Diri akan menaikkan 0,81 unit Komitmen Terhadap Profesi. Selain itu persamaan garis lurus ini juga menyatakan bahwa tanpa kehadiran variabel Efikasi Diri $(X 2=0)$, Guru SMP Swasta Sekecarnatan Tapos Depok telah memiliki Komitmen Terhadap Profesi sebesar 28,23 unit. Hasil uji F pada analisis regresi linear sederhana memperlihatkan hubungan yang signifikan kedua variabel ini. Hal ini mengindikasikan bahwa, adanya pengaruh Efikasi Diri terhadap Komitmen Terhadap Profesi Guru S:MP Swasta Sekecamatan Tapos Depok. Sedangkan koefisien korelasi hubungan antara Efikasi Diri dan 
Komitmen Terhadap Profesi termasuk dalam kekuatan hubungan yang sangat kuat (ry2 $=0,81$ ) dengan tingkat signifikansi sebesar 24,19 (sangat signifikan). Dengan demikian hasil penelitian ini menunjukkan bahwa terdapat hubungan positif yang signifikan dengan kekuatan hubungan yang tinggi antara variabel Efikasi Diri dan Komitmen Terhadap Profesi. Perhitungan koefisien determinasi (ry12 sebesar 0,6580) menunjukkan variabel Efikasi Diri memberikan kontribusi sebesar 65,80\% terhadap kenaikan variabel Komitmen Terhadap Profesi (Y). Sedangkan 34,2\% disumbangkan oleh faktor lainnya yang tidak dibahas dalam penelitian ini. Penelitian ini mendukung penelitian terdahulu yang dilakukan oleh oleh Attri and Devi (2017: 109) yang berjudul "Relationship between professional commitment and self-efficacy of secondary teacher educators". Hasil penelitian menunjukkan bahwa ada hubungan positif antara efikasi diri dan komitmen terhadap profesi dengan kekuatan hubungan $(\mathrm{r}=$ 0,571). Meskipun hasil koefisien korelasi pada penelitian ini berbeda, namun semuanya memberikan kesimpulan yang sarna yaitu bahwa terdapat hubungan positif yang signifikan antara Efikasi Diri dengan Komitmen Terhadap Profcsi

\section{Hubungan Pemberdayaan (XI), variabel Efikasi Diri (X2) Secara Bersama-sama dengan Komitmen Terhadap Profesi (Y).}

Berdasarkan hasil perhitungan analisis regresi linier sederhana dan analisis korelasi ganda, maka didapatkan bahwa hubungan antara variabel Pemberdayaan (Xl) dan Efikasi Diri (X2) secara bersama-sama dengan Komitmen Terhadap Profesi (Y) Guru SMP Swasta Sekecarnatan Tapos Depok, dapat dinyatakan dalam bentuk persamaan garis lurus, yakni $¥=21,89+0,173 X 1+0,67 X 2$. Hal ini berarti bahwa setiap kenaikan satu unit Pemberdayaan dan Efikasi Diri secara bersamasarna akan menaikkan 0, $843(0,173+0,67)$ unit Komitmen Terhadap Profesi . Selain itu persamaan garis lurus ini juga menyatakan bahwa tanpa kehadiran variabel Pemberdayaan (X1) dan Efikasi Diri (X2=0) secara bersama-sama, guru tetap yayasan (GTY) SMA Swasta se-Kecamatan Bogor telah memiliki Komitmen Terhadap Profesi sebesar 21,89 unit. Hasil uji F pada analisis regresi linear berganda memperlihatkan hubungan yang signifikan kedua variabel ini. Hal ini mengindikasikan bahwa, adanya pengaruh Pemberdayaan dan Efikasi Diri secara bersama-sama terhadap Komitmen Terhadap Profesi Guru SMP Swasta Sekecamatan Tapos Depok. Sedangkan koefisien korelasi hubungan antara Pemberdayaan dan Efikasi Diri secara bersama- sama terhadap Komitmen Terhadap Profesi termasuk dalarn kekuatan hubungan yang sangat kuat $(\mathrm{rY} .12=0,834)$ dengan tingkat signifikansi sebesar 10,89 (sangat signifikan). Dengan demikian hasil penelitian ini menunjukkan bahwa terdapat hubungan positif yang signifikan dengan kekuatan hubungan yang tinggi antara variabel Pemberdayaan dan Efikasi Diri secara bersama-sama dengan Komitmen Terhadap Profesi. Perhitungan koefisien determinasi (ry.122 sebesar 0,696) menunjukkan variabel Pemberdayaan dan Efikasi Diri secara bersama-sama memberikan kontribusi sebesar 0,696 yang artinya variabel Pemberdayaan (X1) dan Efikasi Diri (X2) memberikan sumbangan sebesar 69,6\% terhadap kenaikan variabel Komitmen Terhadap Profesi (Y). Sedangkan 30,4\% lainnya disumbangkan oleh faktor lainnya yang tidak diteliti dalam penelitian ini. Berdasarkan pembahasan hasil penelitian di atas, dapat disimpulkan bahwa terdapat hubungan positif yang signifikan dengan kekuatan hubungan yang tinggi antara variabel Pemberdayaan (X1) dan Efikasi Diri (X2) secara bersama-sama dengan Komitmen Terhadap Profesi (Y), yang berrnakna semakin tinggi Pemberdayaan (X I) dan Efikasi Diri (X2) secara bersama-sama, maka semakin tinggi pula Komitmen Terhadap Profesi (Y) yang diperlihatkan Guru SMP Swasta Sekecamatan Tapos Depok.

\section{SIMPULAN}

Berdasarkan analisis terhadap data hasil penelitian dapat disimpulkan terdapat hubungan positif sangat signifikan antara pemberdayaan dengan komitmen profesional, efikasi diri dengan komitmen profesional dan pemberdayaan dan efikasi diri bersamasama dengan komitmen profesional. Berdasarkan hasil penelitian ini maka untuk meningkatkan Komitmen Profesional dapat dilakukan dengan penguatan pemberdayaan dan efikasi diri.

\section{REFERENSI}

Amzat, Ismail Hussein and Nena P Valdez. 2017. Teacher Empowerment Toward Professional Development and Practices. Singapore: Springer Nature.

Bogler, R., \& Somech, A. (2004). "Influence of teacher empowerment on teachers' organizational commitment, professional commitment and organizational citizenship behavior in schools". Teaching and Teacher Education, 277-289. https://doi.org/10.1016/j.tate.2004.02.003

Chatzistamatiou, Mariza, Vasilios Bagiatis and Irini Dermitzaki. 2013. Self-regulatory teaching in mathematics: Relations to teachers' motivation, affect and professional commitment. Lisboa: Science+Business Media.

Colquitt, Jason A., Jeffrey A. Lepine, dan Michael J. Wetson. 2009. Organizational Behavior: Improving Performance and Commitment in the Workplace. Boston: McGraw-Hill.

Goswami, Sanghamitra; Mary Mathew, and N K Chadha. 2007. "Differences in Occupational Commitment amongst Scientists in Indian Defence, Academic, and Commercial R\&D Organizations". Vikalpa Journal, Volume 32, 13-27

Ivancevich, J.M. 2010. Human Resource Management. New York: McGraw-Hill.

Luthans, Fred. 2008. Organizational Behavior (An Evidence-Based Approach) 12th Edition. New York: McGraw-Hill.

Major, Ashley. 2016. "Sources Of Self-Efficacy, Self-Efficacy For Self-Regulated Learning, And Student Engagement In Adolescents With Adhd". Univrsity of Toronto, pp. 34 
McShane, Steven L. and Mary Ann Von Glinow. 2010. Organizational Behavior, 5th Ed. New York: McGraw-Hill

Rice, Aviva Goelman. 2016. "Teacher Empowerment Through Instructional Coaching: A Qualitative Study on the Theory and Application of Partnership Principles”. University Gorgia Digital Commons@ Georgia Southern Electronic, 12

Sezgin, Murat and Celal Cahit Ağar. 2012. "Impact of Affective Organizational and Occupational Commitment on Job Satisfaction". International Journal of Business and Commerce. Vol. 2, No.2, pp. 21-35

Wang, Xiaojin \& Jianrong Shen. 2012. "An Investigation into the Professional Commitment of Chinese Project Management Professionals”. International Journal of Business and Management, Vol. 7, No. 10, pp. 156-166 